\title{
PERPUSTAKAAN PERGURUAN TINGGI DI ERA INDUSTRI 4.0
}

\author{
Janti G. Sujana \\ Perpustakaan IPB University \\ jantigs@gmail.com
}

\begin{abstract}
Abstrak
Pendahuluan. Tuntutan adanya perubahan terhadap perpustakaan perguruan tinggi di era industri 4.0 semakin nyata. Aktivitas berbasis digital semakin menguat dilaksanakan di perguruan tinggi dan masyarakat.

Tujuan. Tulisan ini bertujuan untuk mengetahui tuntutan kebutuhan pengguna perpustakaan masa kini di era industri 4.0, terutama di perguruan tinggi; dan mencoba memberikan saran untuk arah pengembangan perpustakaan perguruan tinggi di era industri 4.0.

Metode. Metode yang digunakan merupakan studi literatur dan observasi pada web perpustakaan perguruan tinggi terkemuka di dunia.

Hasil. Berbagai penelitian menunjukkan pengguna perpustakaan masa kini, terutama di perguruan tinggi, menunjukkan tuntutan akan layanan yang bersifat non-konvensional, walaupun masih ada tuntutan pada layanan yang konvensional. Perpustakaan memiliki big data yang luar biasa berasal dari repositori institusi, informasi registrasi pengguna, informasi perilaku pengguna, informasi tentang interaksi pengguna, dan berbagai catatan tentang perilaku pengguna di jaringan internet lainnya. Era big data memungkinkan untuk mengerti dan terhubung dengan pengguna secara penuh, serta menuntut perpustakaan untuk berubah dari manajemen sumberdaya menjadi manajemen data. Dibahas juga hasil pengamatan pada web perpustakaan dari perguruan tinggi terkemuka yang memperlihatkan betapa perpustakaan-perpustakaan tersebut telah melakukan transformasi layanannya dengan tidak hanya menyediakan dan mendiseminasikan informasi kepada penggunanya, tetapi berperan aktif dalam proses penelitian sivitas akademika dari persiapan penelitian sampai dengan mempublikasikan hasil penelitian. Kompetensi pustakawan menghadapi era industri 4.0 juga dibahas pada tulisan ini.
\end{abstract}

Kata kunci: industri 4.0; kompetensi pustakawan; perpustakaan perguruan tinggi; tuntutan layanan

\begin{abstract}
Introduction. The demand for changes to university libraries in the industrial era 4.0 is increasingly real. Digitalbased activities are getting stronger carried out in universities and the community.

Objectives. This paper aims to find out the demands of today's library users in the industrial era 4.0, especially in universities; and try to provide suggestions for the direction of the development of university libraries in the industrial era 4.0.

Methods. The methods used are literature study and observation on the world's leading university library web.

Results. Various studies show that today's library users, especially in universities, show demands for unconventional services, although there are still demands on conventional services. Libraries have extraordinary big data from institutional repositories, user registration information, user behavior information, information about user interactions, and various records of user behavior on other internet networks. The era of big data makes it possible to fully understand and connect with users, and requires libraries to shift from resource management to data management. The results of observations on web libraries from leading universities are also discussed which show how these libraries have transformed their services by not only providing and disseminating information to their users, but also playing an active role in the academic community's research process from research preparation to publishing research results. The competence of librarians to face the industrial era 4.0 is also discussed in this paper.

Keywords: industry 4.0; librarian competency; service demands; university libraries
\end{abstract}

\section{Pendahuluan}

Akhir-akhir ini masyarakat dunia mengalami kegalauan terkait nasib kehidupannya di masa depan. Kegalauan itu bersumber dari wacana revolusi industri 4.0 yang banyak dibicarakan di mana-mana, yang menyebut ciri-ciri industri 4.0 antara lain big data, internet of things, artificial intelligent, human machine interface, robotic and sensor technology, dan 3D 
printing technology. Bagi orang-orang dengan kemampuan teknologi informasi yang rendah atau bahkan tidak memiliki pengetahuan tentang teknologi informasi, istilah-istilah tersebut sangat asing. Menjadi pertanyaan besar apakah artinya semua itu, dimanakah posisinya dengan semua istilah asing tersebut. Kegalauan itu bertambah lagi dengan runtuhnya beberapa perusahaan besar di dunia dan di Indonesia yang mengakibatkan para pegawai kehilangan pekerjaan.

Kegalauan yang terjadi di bidang perpustakaan sudah dimulai ketika pemanfaatan internet di masyarakat semakin meluas. Informasi yang berlimpah di internet dapat menjadi saingan bagi sumber-sumber informasi yang dikelola perpustakaan. Pustakawan terus mengingatkan bahwa informasi di internet banyak yang tidak benar, tetapi masyarakat, terutama generasi milenial, tetap saja menganggap bahwa informasi yang diperoleh melalui search engine adalah segalanya. Satu dekade terakhir ini fakta di lapangan menunjukkan status perpustakaan sebagai pusat jasa informasi sedang termarjinalkan. Menurut Flood dalam laporannya di majalah the Guardian (6 Desember 2019), negara Inggris telah menutup 773 perpustakaan umum sejak tahun 2010 karena pemerintah harus melakukan penghematan. Gauder (2011 dalam Li et al., 2019) menyampaikan bahwa pada OCLC Library Awareness 2010 (OCLC $=$ Online Computer Library Center) memperlihatkan bahwa sangat sedikit orang yang menggunakan portal perpustakaan untuk mencari informasi (survei yang dilakukan tahun 2005 menunjukkan hanya $1 \%$ ).

Perpustakaan perguruan tinggi memiliki pengguna yang mempunyai keharusan untuk mencari informasi yang spesifik. Mahasiswa dituntut oleh dosennya untuk mengerjakan tugas, membuat makalah dan menulis tugas akhir, yang semuanya memerlukan dukungan informasi yang berkualitas. Namun demikian bukan berarti perpustakaan perguruan tinggi pasti dibutuhkan oleh penggunanya. The Ithaka Institute di Amerika Serikat melakukan survei kepada dosen selama lebih dari tiga tahun mendapatkan bahwa identifikasi pengguna terhadap perpustakaan sebagai portal informasi secara bertahap menurun selama survei berlangsung (Long \& Schonfeld, 2011 dalam Li et al., 2019). Hasil kajian Harrington (2009 dalam Ince, 2018) menunjukkan mahasiswa pascasarjana cenderung bersandar pada teman-teman dan pembimbingnya dari pada meminta bantuan kepada pustakawan dalam memenuhi kebutuhan informasinya. Kasus-kasus tersebut harus menjadi peringatan bagi pustakawan. Kenyataan itu semakin berat dengan masuknya kehidupan manusia pada era industri 4.0. Tulisan ini bertujuan untuk mengetahui tuntutan kebutuhan pengguna perpustakaan masa kini di era industri 4.0, terutama di perguruan tinggi; dan mencoba memberikan saran untuk arah pengembangan perpustakaan perguruan tinggi di era industri 4.0. Metode yang digunakan merupakan studi literatur dan observasi pada web perpustakaan perguruan tinggi terkemuka di dunia.

\section{Perpustakaan dan Industri 4.0}

Merujuk pada ciri-ciri industri 4.0 yang sangat kental keterkaitannya dengan teknologi informasi perpustakaan tidak bisa tinggal diam. Perpustakaan tidak dapat hanya melakukan berbagai pekerjaan konvensional menghadapi tuntutan zaman yang telah berubah sangat jauh. Rektor Institut Pertanian Bogor (IPB) saja mengingatkan IPB menghadapi era industri 4.0 sebagai berikut: "Prestasi masa lalu IPB tak bisa lagi membantu reputasi kita manakala kita tak mampu memberikan kontribusi konkrit saat ini dan masa mendatang" (Satria, 2019). IPB saja sebagai sebuah perguruan tinggi yang termasuk dalam 
lima besar perguruan tinggi di Indonesia, harus berhati-hati menghadapi era perubahan ini, walaupun perguruan tinggi masih menjadi tumpuan generasi muda untuk memperoleh kehidupan yang lebih baik dengan menjadi sarjana. Bandingkan dengan perpustakaan yang di perguruan tinggi berfungsi sebagai unit pendukung berlangsungnya pendidikan, penelitian dan pengabdian pada masyarakat, yang dikenal sebagai Tridharma perguruan tinggi, dimana masih ada orang yang beranggapan bahwa tanpa memanfaatkan perpustakaan orang dapat lulus dari perguruan tinggi. Dengan demikian perpustakaan di perguruan tinggi harus lebih berjuang untuk mempertahankan eksistensinya, perpustakaan harus berkontribusi secara konkrit kepada penggunanya, bila tidak ingin ditinggalkan oleh penggunanya. Perpustakaan tidak dapat hanya mengandalkan layanan peminjaman buku, yang faktanya semakin sedikit buku yang dipinjam mahasiswa. Buku elektronik yang open access dapat diunduh dari internet, dan gerakan open access para ilmuwan membuat semakian banyak buku elektronik dapat diunduh mahasiswa dengan gratis. Penerbitpenerbit komersil besar pun sudah menerbitkan buku dan jurnal open access. Cukup banyak mahasiswa yang mungkin lebih tahu dari pustakawan dimana mendapatkan sumber-sumber informasi gratis untuk bidang ilmunya.

Perpustakaan harus melakukan reformasi pada berbagai layanan yang disediakan, melakukan berbagai inovasi dengan berorientasi pada kebutuhan pengguna. Li et al. (2020) dalam penelitiannya di Perpustakaan Wuhan University, China, mencoba memperkenalkan konsep digital scholarship services. Banyak definisi tentang digital scholarship, diantaranya Kim (2016 dalam Li et al., 2020) mendefinisikan digital scholarship sebagai lebih menyangkut pada penciptaan berbagai pendekatan dan metode untuk pembelajaran dan pencarian intelektual pada digital platforms. Selain itu Ayer (2013), Mitchem \& Rice (2017) (dalam Li et al., 2020) mendefinisikan digital scholarship sebagai berbagai peralatan, teknologi dan metode digital dalam mendukung semua bentuk kegiatan ilmiah. Digital scholarship services diharapkan lebih komprehensif dan sistematis dibandingkan dengan layanan scholarly communication, layanan data penelitian, layanan perpustakaan digital dan layanan dukungan subjek (Mitchem \& Rice, 2017; Tzoc, 2016; Zhou et al., 2019 dalam Li et al., 2020).

Hasil penelitian Li et al. (2020) menunjukkan tuntutan pengguna (dosen dan mahasiswa) akan layanan di luar layanan perpustakaan yang konvensional. Berikut ini sebagian dari layanan yang dituntut oleh para narasumber: metric analysis untuk lebih dapat melihat topik yang akan diteliti; diharapkan perpustakaan dapat membantu peneliti untuk mendapatkan mitra peneliti baik terkait dengan kepakaran tertentu maupun terkait dengan peralatan penelitian, seperti menunjukkan dimana laboratorium yang memenuhi kriteria tertentu; dosen muda membutuhkan bantuan untuk membuat proposal penelitian dan informasi tentang sumbersumber dana penelitian; perpustakaan dapat memberi contoh proposal yang telah sukses mendapat sponsor penelitian; mengadakan pelatihan dan mendukung pelaksanaan penelitian; perpustakaan mengorganisasikan training/workshop dengan mengundang dosen/peneliti yang telah sukses memperoleh dana penelitian; dan di website perpustakaan perlu ada aplikasi untuk sarana penelitian, ada video tentang petunjuk menggunakan sarana penelitian. Hasil penelitian $\mathrm{Li}$ et al. menunjukkan perpustakaan dituntut memberikan layanan di luar layanan yang selama ini dilaksanakan oleh perpustakaan perguruan tinggi, seperti layanan penelusuran informasi, mendiseminasikan informasi, tetapi lebih masuk 
ke proses penelitian dosen dan mahasiswa.

Wuhan University termasuk 10 universitas top di China. Penelitian Li et al. (2020) menyimpulkan pustakawan di Wuhan University Library masih kurang perhatian dan usahanya untuk mengerti kebutuhan peneliti dalam mendapatkan topik penelitian yang tepat, belum bisa mengidentifikasi mitra peneliti yang potensial. Selain itu, peneliti di Wuhan University kurang percaya pustakawan dapat mendukung proses penelitian mereka. Bila pustakawan di Wuhan University Library saja dianggap tidak dapat memenuhi tuntutan layanan perpustakaan masa kini, bagaimana dengan pustakawan di perguruan tinggi Indonesia? Padahal kemungkinan besar perpustakaan perguruan tinggi di China mendapat perhatian lebih besar dari pihak universitas, bila dilihat kemajuan teknologi di China sekarang ini luar biasa, bahkan dikatakan mungkin sudah mengalahkan Amerika Serikat. Kemajuan ilmu pengetahuan dan teknologi yang luar biasa pastilah didukung oleh sumbersumber informasi yang baik, yang dikelola oleh perpustakaan. Bandingkan dengan perpustakaan perguruan tinggi di Indonesia dimana kebanyakan perpustakaan tidak menjadi prioritas pimpinan perguruan tinggi, terutama bila sudah terkait dengan anggaran. Kembali soal tuntutan layanan non konvensional, seorang dosen di IPB menyarankan Perpustakaan IPB mengadakan pelatihan menyusun proposal bagi mahasiswa program sarjana. Walaupun sudah ada mata kuliah "Metode Penelitian" atau "Teknik Menulis Ilmiah", namun mahasiswa masih perlu dibantu dengan pelatihan penyusunan proposal. Jadi tuntutan terhadap peran pustakawan perguruan tinggi untuk memberikan layanan di luar layanan konvensional itu nyata ada. Untuk itu pustakawan perguruan tinggi perlu bekerja sama dengan dosen untuk mengadakan pelatihan penyusunan proposal, dan pustakawan harus percaya diri bahwa setelah beberapa lama pustakawan mendampingi dosen dalam pelatihan tersebut, pustakawan akan mampu mengadakan pelatihan tersebut sendiri. Pustakawan harus dapat menangkap kebutuhan pengguna masa kini, harus berinovasi dan mau terus melengkapi dirinya dengan pengetahuan yang tidak semata-mata terkait dengan dunia kepustakawanan konvensional.

Penelitian Ince (2018) pada layanan mahasiswa pascasarjana sejumlah perpustakaan universitas di Amerika Serikat memberikan beberapa rekomendasi layanan yang sebagian bersifat konvensional, antara lain seperti perlu adanya modul-modul instruksional tentang berbagai layanan dan sumber daya perpustakaan, video tutorial, FAQ (frequently asked questions) berhubungan dengan pertanyaan-pertanyaan referensi, dan adanya "graduate services" di situs web perpustakaan. Terkait situs web perpustakaan, Budzise-Weaver \& Anders (2016 dalam Ince, 2018) berpendapat bahwa situs web perpustakaan diperlukan oleh mahasiswa pascasarjana sebagai entry point untuk memanfaatkan perpustakaan. Jadi penting sekali situs web perpustakaan memberi informasi yang lengkap berhubungan dengan kebutuhan mahasiswa pascasarjana dan juga sivitas akademika lainnya. Dengan search engine akan diperoleh banyak sekali informasi di internet, namun pustakawan dapat membantu penggunanya dengan menyaring sumber-sumber informasi yang valid, akurat dan relevan dan membuat link pada sumber informasi tersebut di situs web perpustakaan. Dengan demikian pengguna akan sangat terbantu, karena menyaring sumber informasi di internet memerlukan strategi dan menghabiskan banyak waktu. Disamping itu Ince (2018) juga menyarankan agar para perpustakaan perguruan tinggi itu melaksanakan layanan data penelitian termasuk 
pelatihan dan/atau panduan penelitian; training tentang riset meliputi strategi mendapat informasi, manajemen data, aplikasi analisis data (perpustakaan menyediakan berbagai aplikasi kuantitatif, kualitatif, dan Geographical Information System); tinjauan literatur; dan bagaimana melakukan publikasi. Kembali terbukti bahwa perpustakaan dituntut untuk lebih memberikan layanan yang terlibat langsung pada proses penyelesaian perkuliahan mahasiswa di perguruan tinggi, yaitu dalam proses penyusunan tugas akhir mahasiswa.

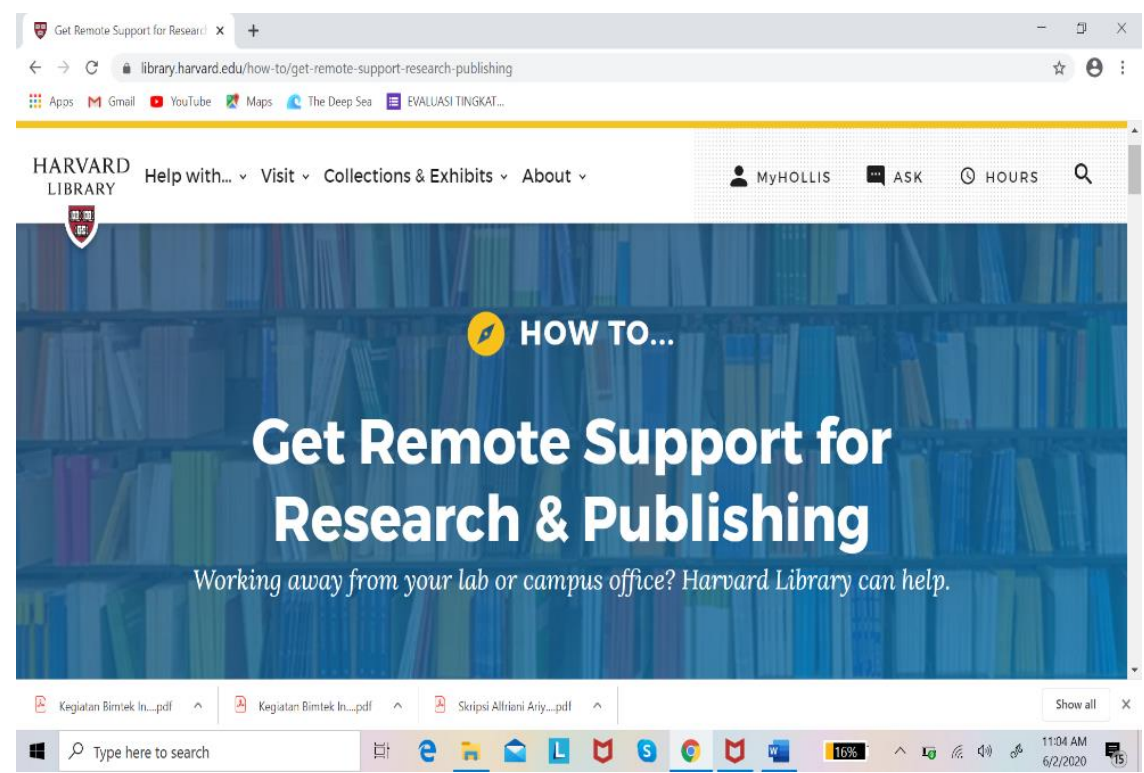

Gambar 1. Layanan dukungan perpustakaan pada penelitian dan publikasi di Harvard University Library Sumber: https://library.harvard.edu/how-to/get-remote-support-research-publishing (diunduh 5 Juni 2020)

Selanjutnya penulis mencoba memberikan ilustrasi nyata bagaimana perguruan tinggi di negara maju telah memberikan layanan yang sesuai dengan tuntutan pengguna masa kini. Gambar 1 menunjukkan halaman situs web Harvard Library yang mengumumkan kepada sivitas akademika Harvard University adanya layanan yang diberikan oleh perpustakaan untuk mendukung proses penelitian dan publikasi mereka. Harvard Library memberikan layanan "Connect with Research Experts"; mengadakan berbagai workshop seperti "Introduction to NVivo for Mac", "Preparing for Qualitative Field Work", "Interview Skills"; "Find Existing Datasets and Sources"; "Storing and Sharing Your Research"; dan lain-lain.

Contoh layanan masa kini lainnya diambil dari Peking University Library, seperti terlihat pada Gambar 2. Peking University Library memberikan layanan

\begin{abstract}
"Research Support" seperti "Library Workshop" dimana perpustakaan tersebut mengadakan workshop antara lain "document retrieval and utilization", "database searching", "academic writing and software application"; "Academic Frontier Tracing"; "Research Subjects Consultation"; "Disciplinary Open Data Navigation"; "Submitting Manuscripts"; dan lain-lain. Harvard University dan Peking University memang universitas papan atas di dunia, mungkin ada yang berpendapat terlalu jauh membandingkan perguruan tinggi di Indonesia dengan Harvard University atau Peking University. Namun demikian, perlu diingat Bung Karno, Presiden pertama RI pernah berucap "Gantungkan cita-citamu setinggi langit! Bermimpilah setinggi langit. Jika engkau jatuh, engkau akan jatuh di antara bintang-bintang". Cita-cita yang tinggi membuat kita bersemangat untuk mencapainya.
\end{abstract}




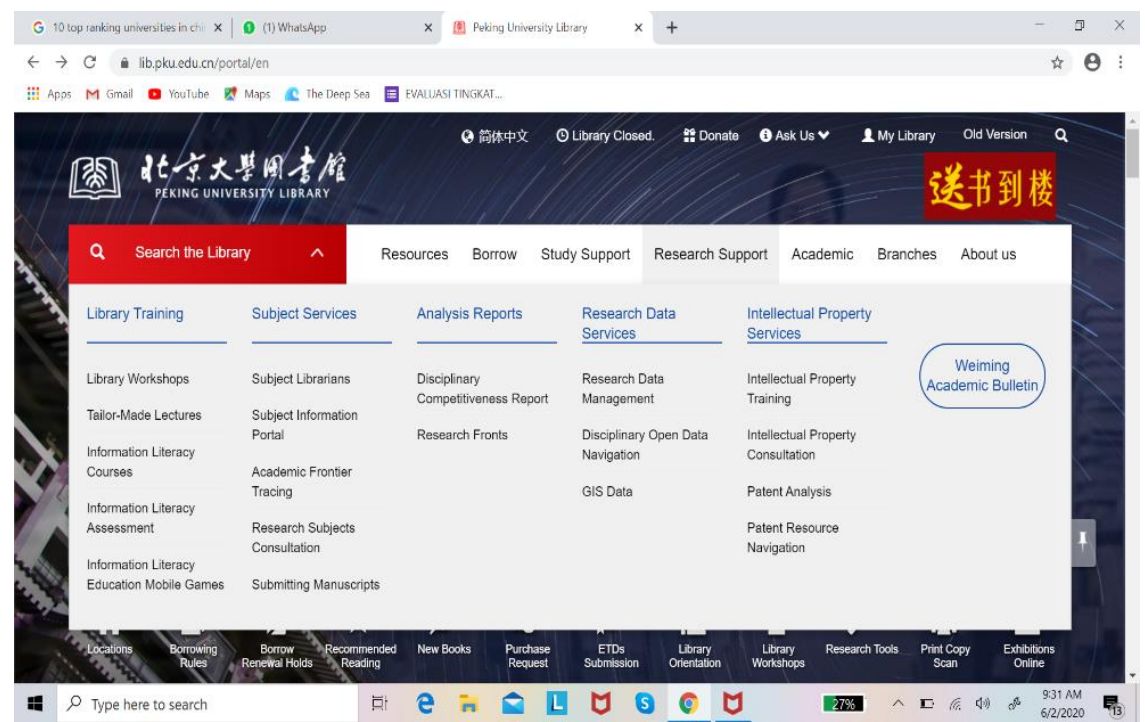

Gambar 2. Layanan dukungan perpustakaan pada penelitian di Peking University Library Sumber: https://www.lib.pku.edu.cn/portal/en (diunduh 5 Juni 2020)

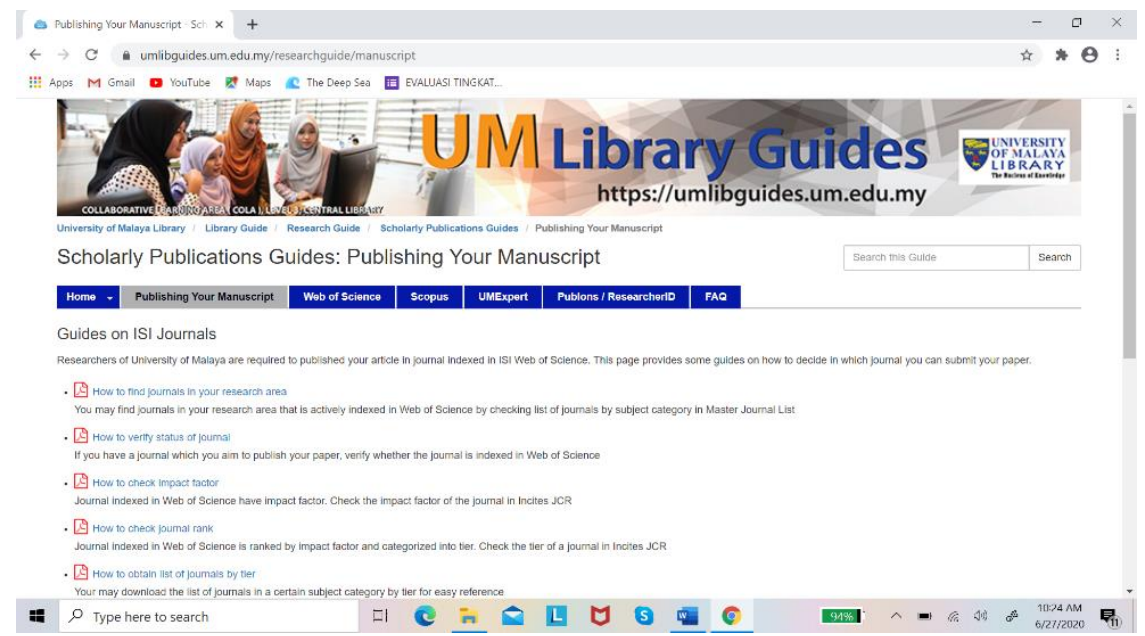

Gambar 3. Layanan dukungan perpustakaan pada penelitian di University of Malaya, Malaysia Sumber: https://umlibguides.um.edu.my/researchguide/manuscript (diunduh 27 Juni 2020)

Penulis mencoba melihat perpustakaan perguruan tinggi di negara tetangga, yaitu University of Malaya, universitas peringkat ketiga di Asia Tenggara. Pada situs web University Malaya sudah ada hyperlink "Research Support", meliputi "Liaison Librarians"; "Librarian in Research Methodology"; "Research Guides"; "Deposit in UM Research Repository"; "APA Formatting \& Style Guide"; dan "Research Tools". Gambar 3 merupakan bagian dari "Research Guides", yaitu "Publishing Your Manuscript". Perpustakaan University of Malaya membantu sivitas akademika mendapatkan berbagai jurnal di bidang ilmunya, mengecek status jurnal untuk mempublikasikan hasil penelitiannya, mengecek impact factor jurnal, dan lain-lain. Perpustakaan-perpustakaan di bawah perguruan tinggi yang termasyhur memang memiliki fasilitas pendukung yang sangat baik, namun di era open access ini cukup banyak sumber-sumber informasi tidak berbayar yang dapat dimanfaatkan selama pustakawannya tekun terus menelusuri sumber-sumber yang tersedia.

Layanan data penelitian sekarang ini sudah semakin banyak dilaksanakan di 
perpustakaan perguruan tinggi di negaranegara maju. Gambar 4 menunjukkan situs web layanan data penelitian di Columbia University Libraries, Amerika Serikat dan Gambar 5 situs web layanan data penelitian di the University of Manchester Library, Inggris. Pengelolaan data penelitian ini sangat bermanfaat bagi kemajuan ilmu pengetahuan dan teknologi, dan juga menyebabkan penghematan dana dan waktu untuk pelaksanaan penelitian. Beberapa dosen IPB menyatakan bahwa data hasil penelitian yang disimpan dalam database akan sangat berguna bagi pengembangan ilmu pengetahuan. Data yang dihasilkan saat ini, pada lima atau sepuluh tahun ke depan mungkin dengan kemajuan teknologi yang lebih canggih, ketika diolah lagi akan dapat menghasilkan kesimpulan yang lebih baik dari yang dihasilkan saat ini (Sujana et al., 2019). Dapat dibayangkan seperti di IPB saja setiap tahun menghasilkan sekitar 4000an lulusan, artinya ada sekitar 4000-an data penelitian telah dihasilkan. Universitas Indonesia dan Universitas Gajah Mada tentunya lebih banyak lagi jumlah lulusan yang dihasilkan, mengingat jumlah mahasiswa kedua perguruan tinggi itu jauh lebih banyak dari jumlah mahasiswa IPB. Bayangkan seberapa besar manfaat bisa diperoleh dari data yang begitu banyak, terlebih sekarang ini memang era big data.

Data hasil penelitian di Indonesia baru dikumpulkan oleh Pusat Data dan Dokumentasi Ilmiah, Lembaga Ilmu Pengetahuan Indonesia. Sebenarnya telah keluar Undang-Undang Nomor 11 Tahun 2019 tentang Sistem Nasional Ilmu Pengetahuan dan Teknologi dimana pada Pasal 40 disebutkan "Pemerintah Pusat menetapkan wajib serah dan wajib simpan atas seluruh data primer dan keluaran hasil Penelitian, Pengembangan, Pengkajian, dan Penerapan”. Wajib serah dan wajib simpan data hasil penelitian itu wajib dilakukan oleh Kelembagaan Ilmu Pengetahuan dan Teknologi, dimana perguruan tinggi termasuk di dalamnya. Perpustakaan perguruan tinggi di negaranegara maju berupaya menjaga eksistensinya di perguruan tingginya dengan berbagai cara, termasuk dalam mengelola data penelitian sivitas akademikanya. Perpustakaan perguruan tinggi di Indonesia juga harus berjuang keras meyakinkan pimpinan perguruan tinggi bahwa perpustakaan mampu mengelola data hasil penelitian. Perpustakaan sudah terbiasa mengelola database katalog koleksi, dan belakangan ini juga mengelola repositori. Jadi pustakawan pasti bisa juga mengelola database data hasil penelitian.

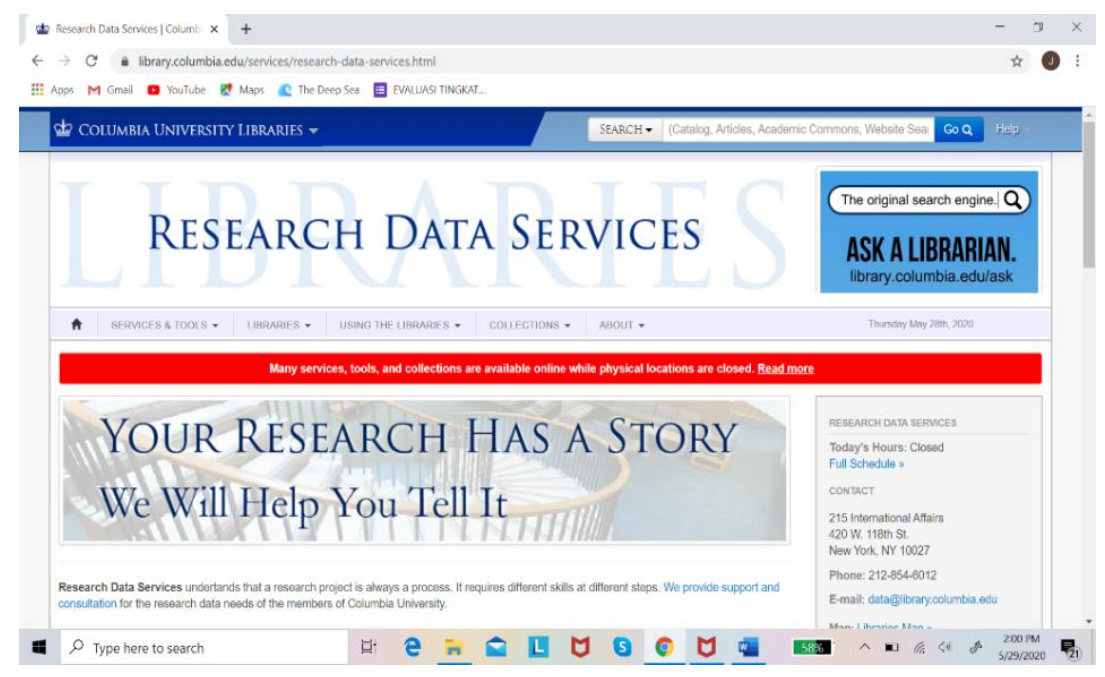

Gambar 4. Layanan data penelitian di Columbia University Libraries, Amerika Serikat Sumber: https://library.columbia.edu/services/research-data-services.html (diunduh 29 Mei 2020) 


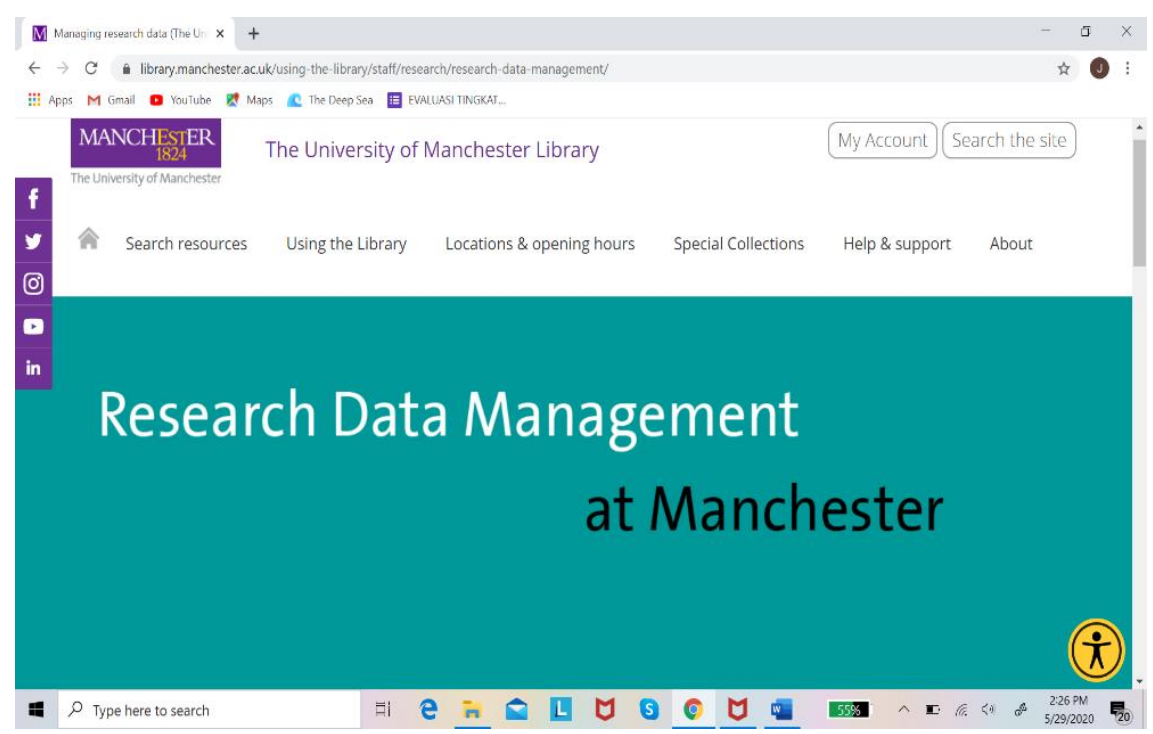

Gambar 5. Layanan data penelitian di University of Manchester Library, Inggris

Sumber: https://www.library.manchester.ac.uk/using-the-library/staff/research/research-data-management/ (diunduh 29 Mei 2020)

Di era industri 4.0 perpustakaan perlu menyediakan coworking space, tempat yang nyaman untuk mahasiswa dan dosen bekerja menghasilkan inovasi yang menjadi tuntutan era industri 4.0. Namun demikian, perpustakaan janganlah bergembira bila hanya dijadikan coworking space. Pada awal bulan Maret 2020, karena IPB harus melakukan efisiensi maka Pimpinan IPB memutuskan Perpustakaan IPB hanya buka selama jam kerja kantor, tidak ada ekstra jam layanan. Pengambil keputusan mungkin berasumsi bahwa informasi sekarang ini dapat diakses dari mana saja, sehingga perpustakaan jam bukanya dikurangi pun tidak jadi masalah. Ternyata pengurangan jam layanan itu diprotes oleh mahasiswa. Mereka membuat petisi yang ditandatangani oleh hampir 1000 mahasiswa. Muncul berbagai komentar di media sosial, seperti "save perpustakaan", "pak Rektor tesis saya tidak cepat selesai kalau perpustakaan tutup pk 16", dan lain-lain. Apakah itu menandakan perpustakaan sangat dibutuhkan oleh mahasiswa? Hal itu benar untuk perpustakaan sebagai coworking space. Pustakawan perlu berpikir bila perpustakaan hanya sebagai coworking space, apakah pustakawan diperlukan? Sebagai catatan pada kasus di
Perpustakaan IPB, layanan di luar jam kerja kantor dapat dikatakan bahwa kebanyakan pemustaka bekerja mandiri atau datang untuk meminjam atau mengembalikan buku. Kalau perpustakaan hanya sebagai coworking space, mungkin anak-anak lulusan Sekolah Menengah Atas atau lebih tepatnya anakanak Sekolah Menengah Kejuruan berbasis teknologi informasi cukup untuk menjaga coworking space. Masalah yang mungkin sering muncul adalah mahasiswa komplain komputernya error atau sambungan internetnya lamban. Pustakawan harus lebih berperan dalam membantu mahasiswa agar mahasiswa mendapat informasi akurat, valid dan relevan. Pustakawan harus dapat membuat mahasiswa literat informasi, walaupun ternyata di era industri 4.0 tuntutan pengguna lebih dari itu.

Dalam rangka mempersiapkan generasi muda yang siap menghadapi kehidupan yang semakin kompetitif di era industri 4.0, Menteri Pendidikan, Kebudayaan, Riset dan Teknologi telah menetapkan program kampus merdeka, dimana mahasiswa selama 3 semester dapat belajar di luar program studinya. Mahasiswa dapat belajar di perguruan tinggi lain, magang/praktik kerja, kuliah kerja nyata tematik, kegiatan wirausaha, 
asistensi mengajar di satuan pendidikan, dan lain-lain. Perpustakaan perguruan tinggi harus bersiap menghadapi kebijakan tersebut. Program kampus merdeka tersebut membuat perpustakaan harus memikirkan pengaksesan informasi dari luar kampus, tanpa mahasiswa datang ke perpustakaan. Apakah peraturan yang selama ini dianut oleh banyak perpustakaan bahwa untuk meminjam buku tercetak mahasiswa yang bersangkutan harus datang langsung ke perpustakaan, tetap berlaku? Sebenarnya dengan adanya pandemi covid 19 perpustakaan sudah berlatih untuk menyelenggarakan layanan secara daring, tinggal menetapkan bahwa layanan secara daring akan menjadi kebiasaan baru di perpustakaan. Selama pandemi ini pengembalian buku-buku tercetak yang dipinjam mahasiswa dikembalikan melalui pos atau layanan paket dengan kurir, begitu juga dengan pengiriman tugas akhir tercetak (tentunya bagi perguruan tinggi yang masih memberlakukan pengumpulan hard copy tugas akhir mahasiswa). Dengan demikian, apakah peminjaman buku tercetak dapat dilakukan tanpa mahasiswanya datang ke perpustakaan, karena yang bersangkutan sedang kuliah atau bekerja di daerah yang jauh dari perguruan tinggi aslinya? Apakah perpustakaan sebaiknya sudah mem-percayai bahwa buku-buku yang dikirim melalui layanan paket dengan kurir akan sampai dengan selamat? Bukankah akhir-akhir ini masyarakat telah terbiasa membeli baju, sepatu, bahkan barang-barang elektronik secara daring dan barang pesanan diantar oleh layanan paket dengan kurir? Perpustakaan perlu terus berubah, beradaptasi dengan zaman yang telah jauh berubah.

Merujuk pada arah kecenderungan kegiatan sivitas akademika yang semakin kuat ke arah berbasis digital, perpustakaan perguruan tinggi perlu meninjau kebijakan pengembangan koleksinya. Porsi pengadaan buku teks, jurnal, prosiding, sumber-sumber informasi referensi, dan lain-lain dalam format digital tentunya menjadi lebih dominan. Dari proses pengadaannya bahan perpustakaan digital ini lebih mudah dan cepat, tidak perlu menunggu pengiriman secara fisik, namun pustakawan harus mempelajari produk yang ditawarkan pihak vendor dengan cermat. Selain itu sosialisasi penggunaan bahan perpustakaan digital perlu dilakukan secara intensif melalui panduan baik berupa teks ataupun video, yang dapat diakses oleh sivitas akademika setiap saat. Pemantauan pemanfaatan koleksi digital perlu dilakukan terus menerus, agar dana yang telah dikeluarkan tidak mubazir.

\section{Perpustakaan dan Big Data}

Big data merupakan salah satu ciri dari industri 4.0. Big data dapat menjadi cara baru melihat dunia secara lengkap berdasarkan pengumpulan sebanyak mungkin fakta dan data untuk membuat keputusan. Semakin banyak data diperoleh, semakin mengurangi ketidakpastian, dan lebih memungkinkan mencipta pengetahuan dengan nilai yang lebih. Narendra (2015) mengatakan karakteristik big data terletak pada volume, velositas, dan varietas serta value. Qian et al. (2015 dalam Li et al., 2019) menyatakan bahwa dengan big data, himpunan data dapat membawa pada penemuan pengetahuan baru.

Bagaimana dengan big data di perpustakaan? Perpustakaan kaya akan big data. Menurut Li et al. (2019) pada pengelolaan digital library perpustakaan memiliki informasi registrasi pengguna, informasi perilaku pengguna (seperti sejarah browsing, temu kembali informasi dan yang diunduh), informasi tentang interaksi pengguna, dan berbagai catatan tentang perilaku pengguna di jaringan internet (logs) lainnya. Dengan menganalisis data pengguna dan mengkombinasikan dengan informasi sosial pengguna di web, perpustakaan bisa melakukan analisis yang lebih lengkap dan akurat tentang kebiasaan 
membaca, perilaku pemanfaatan sumber daya, dan penggunaan jaringan. Era big data memungkinkan untuk mengerti dan terhubung dengan pengguna secara penuh. Interaksi diantara pengguna dengan perpustakaan tidak hanya memenuhi kebutuhan informasi pengguna, tetapi juga memberikan secara kontinu lebih banyak sumber daya pengguna ke perpustakaan. Dengan mengeksploitasi sumber daya pengguna, perpustakaan digital dapat mempunyai perspektif yang lebih luas pada pembangunan sumber daya data. Terkait dengan digital library, pemikiran big data akan memfasilitasi inovasi manajemen dan layanan (Zeng, 2014 dalam Li et al., 2019). Gao (2015 dalam Li et al., 2019) menyatakan lingkungan big data membutuhkan perubahan dalam pemikiran manjemen perpustakaan, dari manajemen sumber daya ke manajemen data.

Sementara itu beberapa pakar mengusulkan reformasi perpustakaan di masa lingkungan big data dilaksanakan pada 3 aspek yaitu pembangunan sumber daya, penerapan teknologi dan layanan perpustakaan. Untuk pembangunan sumber daya diperlukan untuk memperluas cakupan sumber daya. Pada aplikasi teknologi, teknologi semantik haruslah menjadi fokus perhatian, aplikasi teknologi pengklusteran haruslah diperkuat, teknologi analisis data seharusnya digunakan secara luas, teknologi temu kembali seharusnya diperbaiki. Terkait dengan layanan, layanan perpustakaan digital haruslah diperkaya dengan merubah berbagai layanan dari model pasif ke model yang lebih proaktif, otomatis, dan personalisasi (Su, 2015 dalam Li et al., 2019). Banyak perpustakaan perguruan tinggi telah mengelola repositori institusinya, sebuah big data yang sangat luar biasa bila dapat mengolah datanya. Terlebih bila perpustakaan dipercaya juga mengelola data hasil penelitian institusinya akan membuat perpustakaan sebagai pusat big data yang lebih dibutuhkan oleh sivitas akademikanya.

\section{Perpustakaan dan Media Sosial}

Menghadapi pengguna yang kebanyakan generasi milenial, perpustakaan dituntut memanfaatkan medial sosial. Media sosial sangat bermanfaat untuk menyebarkan berbagai informasi karena dapat menyebar dengan cepat. Perpustakaan IPB dengan mudah mengumumkan pelatihan e-resources kepada mahasiswa pascasarjana melalui Whatsapp dengan pihak Forum Mahasiswa Pascasarjana. Forum itu mempunyai jaringan komunikasi dengan para mahasiswa pascasarjana melalui Whatsapp. Pengumuman yang ditempel di perpustakaan tidak efektif, tidak dapat menjangkau mahasiswa dalam jumlah banyak.

Lam et al. (2019) melakukan penelitian tentang penggunaan Facebook di perpustakaan-perpustakaan universitas di Hongkong. Penelitian ini mengamati "Like", "Comments" dan "Shares" menjadi ukuran keberhasilan berkomunikasi melalui Facebook. "Like" menyatakan apresiasi dari users, dapat mengukur popularitas; "Comments" cara aktif untuk berinteraksi dengan users, dapat mengukur komitmen; dan keviralan diukur dengan jumlah "Shares".

Facebook menyediakan kesempatan yang luar biasa untuk perpustakaan berinteraksi dengan penggunanya secara mendalam, alat pemasaran bagi perpustakaan perguruan tinggi, terutama untuk promosi acara-acara yang diadakan perpustakaan. Hasil penelitian Lam et al. (2019), begitu juga Al-Daihani \& Abrahams (2018), Joo et al. (2018) (dalam Lam et al., 2019) menunjukkan bahwa kata-kata yang personal seperti ucapan "selamat", "terima kasih" dan pesan-pesan inspiratif lainnya menyebabkan keterkaitan pengguna dengan perpustakaan. Untuk mendorong lebih banyak respon dan untuk memberi kesan bersahabat dengan pelanggan, 
pustakawan disarankan menghindari bahasa formal yang berlebihan, lebih menampilkan pesan-pesan yang manusiawi atau yang menyentuh perasaan secara positif seperti pesan-pesan yang memberi semangat menjelang periode mahasiswa ujian dan pemberian ucapan selamat menjelang wisuda para lulusan. Menurut Garcia-Milian et al. (2012 dalam Lam et al., 2019) postingan video membantu menarik lebih banyak followers.

Pemanfaatan Facebook dianggap sangat efektif untuk mendapatkan informasi yang dibutuhkan. Seorang dosen IPB mengatakan bahwa belakangan ini beliau dengan cepat mendapatkan artikel jurnal dari Facebook komunitasnya. Sebelumnya beliau meminta bantuan dari mantan mahasiswanya yang sedang melanjutkan studi di perguruan tinggi di luar negeri, tetapi sekarang ini lebih cepat mendapatkan artikel yang dibutuhkan melalui Facebook. Perpustakaan dianggap kurang dapat memenuhi kebutuhan informasinya.

\section{Pustakawan Di Era Industri 4.0}

Berbicara tentang perpustakaan di era industri 4.0 tentunya harus dilengkapi juga pembahasan pustakawan di era industri 4.0. Pratama (2018) mengatakan bahwa 3 literasi utama yang harus dimiliki pustakawan di era revolusi industri 4.0 adalah literasi digital, literasi teknologi, dan literasi manusia. American Library Association (2013 dalam Techataweewan \& Prasertsin, 2018) mendefinisikan literasi digital sebagai kemampuan menggunakan teknologi informasi dan komunikasi untuk mendapatkan, mengevaluasi, menciptakan dan mengkomunikasikan informasi, membutuhkan keterampilan kognitif dan teknis. Techataweewan \& Prasertsin (2018) dari hasil penelitiannya kepada mahasiswa Thailand program sarjana mendefinisikan literasi digital sebagai sekumpulan kemampuan memanfaatkan dan sadar akan informasi, teknologi dan media digital untuk melakukan penelusuran, mengevaluasi, mencipta dan mengkomunikasikan sesuai kebutuhan. Definisi itu mengkombinasikan literasi teknologi informasi dan komunikasi dan literasi informasi. Terkait dengan literasi teknologi, Maryland State Department of Education (2005 dalam Nasution, 2018) mendefinisikan lilterasi teknologi sebagai kemampuan untuk menggunakan, memahami, mengatur, dan menilai suatu inovasi yang melibatkan proses dan ilmu pengetahuan untuk memecahkan masalah dan memperluas kemampuan seseorang. Literasi manusia adalah kemampuan berkomunikasi dan penguasaan ilmu desain (Aoun, 2017 dalam Pratama, 2018). Menurut penulis ada satu lagi literasi yang harus dikuasai juga oleh pustakawan, mengingat di era industri 4.0 pustakawan harus banyak berurusan dengan data, yaitu literasi data. Burress, Mann, \& Neville (2020) mendefinisikan literasi data adalah kemampuan untuk mengakses, menilai, memanipulasi, meringkas dan menyajikan data. Literasi data dapat dianggap sebagai manifestasi baru dari literasi informasi di era big data. Li et al. (2019) menyarankan pustakawan perlu mempunyai keahlian statistika, ilmu komputer dan ilmu informasi. Narendra (2015) juga berpendapat bahwa di era big data pustakawan dituntut untuk dapat menganalisis data dan banyak bersentuhan dengan penguasaan teknologi informasi.

Terkait keahlian statistika, tahun 2019 seorang dosen IPB mengatakan ia baru kembali dari Malaysia mengikuti pelatihan statistika di sebuah universitas yang diadakan oleh perpustakaan universitas tersebut. Yang menarik dosen itu mengatakan bahwa pada hari pertama pelatihan, dimana materi pelatihan yang diajarkan merupakan statistika yang sederhana, yang mengajar adalah pustakawan. Baru pada hari kedua dimana materinya statistika yang lebih kompleks yang mengajar seorang dosen. 
Pustakawan masa kini harus menguasai statistika, walaupun yang sederhana.

\section{Penutup}

Mempelajari berbagai artikel jurnal, situs web berbagai perpustakaan perguruan tinggi dan sumber-sumber informasi lainnya, apa yang telah dilakukan oleh pustakawan di negaranegara lain sudah jauh melangkah. Perpustakaan perguruan tinggi di Indonesia masih berkutat dengan literasi informasi, sedangkan tuntutan pengguna di era industri 4.0 sudah ke literasi digital, literasi teknologi dan literasi data. Perpustakaan perguruan tinggi di era industri 4.0 tidak hanya memberi layanan penyediaan informasi, tetapi dituntut untuk lebih berpartisipasi pada proses penelitian sivitas akademika perguruan tingginya dari awal sampai hasil penelitian itu dipublikasikan. Perpustakaan perguruan tinggi Indonesia diharapkan mengharuskan pustakawannya untuk terus meningkatkan keterampilan literasi informasi, literasi digital, literasi teknologi dan literasi data. Berbagai pelatihan perlu dilakukan untuk menigkatkan kompetensi pustakawan agar mumpuni dalam memenuhi tuntutan pengguna di perguruan tinggi di era industri 4.0.

Forum Perpustakaan Perguruan Tinggi (FPPTI), Ikatan Sarjana Ilmu Perpustakaan dan Informasi Indonesia (ISIPII) dan Perpustakaan Nasional RI diharapkan bekerja sama mendukung penyelenggaraan berbagai pelatihan yang dapat meningkatkan kompetensi pustakawan di era industri 4.0. Kurikulum pendidikan formal di berbagai jurusan atau program studi ilmu perpustakaan dan informasi diharapkan juga disesuaikan dengan perkembangan kebutuhan masyarakat di era industri 4.0, sehingga lulusannya dapat menjadi pustakawan yang handal yang dapat memenuhi tuntutan pengguna di era industri 4.0. Perpustakaan perguruan tinggi Indonesia perlu terus berjuang mempertahankan eksistensinya, meyakinkan pimpinan perguruan tinggi bahwa perpustakaan dapat diandalkan menjadi mitra yang mendukung sivitas akademika menghasilkan inovasi yang menjadi salah satu tuntutan di era industri 4.0. Bila memperhatikan kiprah pustakawan-pustakawan muda di Indonesia, penulis optimis bahwa perpustakaan perguruan tinggi Indonesia dapat diandalkan dalam mendukung perguruan tinggi di era industri 4.0.

\section{Daftar Pustaka}

Arkeman, Y., Buono, A., \& Seminar, K.B. (2019). Revolusi industri 4.0. Dalam Safari, A., Aruman, A.E., \& Anggraini, E. (ed.). IPB 4.0: Pemikiran, gagasan, dan implementasi, hlm. 1-5. Bogor: IPB Press.

Burress, T., Mann, E. \& Neville, T. (2020). Exploring data literacy via a librarian faculty learning community: A case study. The Journal of Academic Librarianship, 46, 102076 https://doi.org/10.1016/j.acalib.2019.1020 76.

Flood, A. (2019). Britain has closed almost 800 libraries since 2010, figures show. The Guardian, 6 December. Diunduh dari https://www.theguardian.com/books/ 2019/dec/06/britain-has-closed-almost800-libraries-since-2010-figures-show.

Ince, S. (2018). Trends in academic libraries graduate student services: A case study. The Journal of Academic Librarianship, 44, 426-429. https://doi.org/10.1016/j.acalib.2018.02.0 12.

Lam, E.T.H., Au, C.H., Chiu, D.K.W. (2019). Analysing the use of Facebook among university libraries in Hong Kong. The Journal of Academic Librarianship, 45, 175-183. https://doi.org/10.1016/ j.acalib.2019.02.007.

Lie, B., Song, Y., Lu, X., \& Zhou, L. (2020). Making the digital turn: Identifying the user requirements of digital scholarship services in university libraries. The Journal of Academic Librarianship, 46, 1-10. https://doi.org/10.1016/j.acalib.2020.1021 35.

Li, S., Jiao, F., Zhang, Y. \& Xu, X. (2019). Problems and changes in digital libraries in the age of big data from the perspective of user services. The Journal of Academic Librarianship, 45, 22-30. https:// doi.org/10.1016/j.acalib.2018.11.012. 
Narendra, A.P. (2015). Data besar, data analisis, dan pengembangan kompetensi pustakawan. Record and Library Journal, 1(2), 83-93.

Nasution, S.H. (2018). Pentingnya literasi teknologi bagi mahasiswa calon guru matematika. Jurnal Kajian Pembelajaran Matematika, 2(1), 14-18.

Pratama, P. (2018). Revolusi industry 4.0: peluang pengembangan perpustakaan berbasis teknologi informasi. Media Pustakawan, 25(3), 35-41.

Satria, A. (2019). Inspirasi, inovasi, dan integritas. Dalam Safari, A., Aruman, A.E., \&
Anggraini, E. (ed.) IPB 4.0: Pemikiran, gagasan, dan implementasi, hlm. v-x. Bogor: IPB Press.

Sujana, J.G., Siswadi, F., \& Isriyanti. (2019). Layanan manajemen data penelitian di Perpustakaan IPB: Sebuah tantangan. Bogor: Perpustakaan IPB.

Techataweewan, W. \& Prasertsin, U. (2018). Development of digital literacy indicators for Thai undergraduate students using mixed method research. Kasetsart Journal of Social Sciences, 39, 215-221. http:// dx.doi.org/10.1016/j.kjss.2017.07001. 